\title{
JAKOBS'UN DÜŞMAN CEZA HUKUKU KAVRAMI HUKUKUN DÜŞMANI
}

\author{
The Concept of Feindstrafrecht; Ultima Ratio-Doctrine an Enemy of \\ Law
}

Prof. Dr. Henning ROSENAU*

Çev.: Dr. iur. Erhan TEMEL**

\section{Düşman Ceza Hukuku Kavramı Alman Ceza Kanununa mı Alınıyor?}

23.7.2004 tarihinde Genel Güvenliğin Korunması Amacıyla Mükerrer Faillere Uygulanacak Hürriyeti Kısıtlayıcı Tedbirleri Düzenleyen Kanun ${ }^{1}$ yürürlüğe girdi. $\mathrm{Bu}$ yasal reformun en önemli kısmını, Ceza Kanunu m. $66 b^{\prime} \mathrm{de}^{2}$ düzenlenen sonradan verilen güvenlik amaçlı hürriyeti kısıtlayıcı

*Augsburg Üniversitesi Hukuku Fakültesi Öğretim Üyesi (Makale 12 Ocak 2008 tarihinde Dokuz Eylül Hukuk Fakültesinde Hukukun Aktüel Sorunları konulu 1. Türk-Alman Hukuk Sempozyumunda tebliğ olarak sunulmuştur).

** LL.M. - Augsburg Üniversitesi Hukuk Fakültesi Öğretim Üyesi, Türk Hukuku Araştırma Merkezi Direktörü.

${ }^{1}$ BGB1. I 2004, 1838.

2 “(1) Hayata, vücut bütünlüğüne, kişisel özgürlüğe ya da kişinin cinsel tercihi aleyhine işlenen suçlarda ya da $\S \S 250,251$ 'de belirtilen suçlarda veya $\S \S 252,255$ ile bağlantılı olarak, hüküm verildikten sonra ya da $\S 66$ f. 3 cümle 1'de belirtilen kabahatten sonra, hürriyeti bağlayıcı cezanın infazının bitmesinden önce, hükümlünün kamu için önemli derecede tehlike arz ettiğini gösteren emarelerin bulunması durumunda, mahkeme sonradan güvenlik amaçlı emniyet tedbiri uygulanmasına hükmedebilir, eğer hükümlünün genel değerlendirilmesinde, işlediği fiillerinden ve cezanın infazı sırasındaki gelişiminden, hükümlünün mağdurun bedeni ve ruhsal sağlığına ağır bir şekilde zarar verecek bir fiili tekrar işlemesi kuvvetle muhtemel olduğu sonucu çıkarılıyorsa ve $\S 66$ 'da belirtilen diğer koşullar yerine gelmişse.

(2) Bir ya da daha fazla hayata, vücut bütünlüğüne, kişisel özgürlüğe ya da kişinin cinsel tercihi aleyhine ya da $\S \S 250,251$ 'de belirtilen suçlarda ve yine $\S \S 252,255$ ile bağlantılı olarak işlenen suç veya suçlarda en az beş yıllık hürriyeti bağlayıcı cezaya hükmedildikten 
emniyet tedbiri oluşturmaktadır. Şu an Alman ceza doktrininde yapılan şiddetli ve geniş kapsamlı tartışmalara ve oluşan genel kanıya bakılırsa, Günther Jakobs tarafindan bulunan Düşman Ceza Hukukunun bir elementinin, artık Alman ceza hukukunun bir bölümünü oluşturmuş olduğu kanısına varılabilir.

Kamu menfaati amaciyla hürriyeti kısıtlama tedbiri kurumu, bugün artık akla gelebilen her versiyonu ile yasada yerini almıştır. Hürriyeti kısıtlama, klasik şekliyle; saklı tutulan ve yeni yasal düzenlemeyle birlikte sonradan verilebilen olmak üzere iki türdür ve bu haliyle Alman hukukunun kabul ettiği en radikal (esaslı) emniyet tedbirlerinden birini oluşturmaktadır.

Hürriyeti kısıtlama tedbiri, ceza hukuku alanında tehlikenin önlenmesi anlamına gelmektedir. Burada failin iyileştirilmesi ön planda olmayıp, sadece ve sadece kamunun güvenlik menfaatinin, tekrar suç işleme olasıllığ olan, aşırı tehlikeli mükerrer failler karşısında korunması söz konusudur ${ }^{3}$ (bkz. Alman CK m. 66 1/3 açık hükmü) ${ }^{4}$. O halde failin kusuru hiçbir rol oynamamaktadır. Öyle ki, fail kusuruna orantılı cezasını çekmiş dahi olsa, (tekrar) hürriyeti kısıtlama tedbirine başvurulması hukuka uygundur.

Jakobs bu durumdan şu sonuca varmaktadır: Prensip olarak kendisine hürriyeti kısıtlama tedbiri uygulanan kimse ile fail kavramını biri birinden

sonra, birinci fikrada belirtilen şekildeki olgular (emareler) bulunuyorsa, mahkeme sonradan güvenlik amaçlı emniyet tedbiri uygulanmasına hükmedebilir, eğer hükümlünün genel değerlendirilmesinde, işlediği fiillerinden ve cezanın infazı sırasındaki gelişiminden, hükümlünün mağdurun bedeni ve ruhsal sağlığına önemli bir zarar verecek ağır fiilleri işlemesi kuvvetle muhtemel olduğu sonucu çıkarılıyorsa.

(3) Karar anında, kusur ehliyetini tamamen ortadan kaldıran ya da azaltan durumun bulunmaması nedeniyle, psikiyatrik bir hastaneye yatırılma kararı mahkeme tarafindan geçersiz kılınmasından (hükümsüz ilan edilmesinden) sonra, mahkeme sonradan emniyet tedbiri uygulanmasına hükmedebilir, eğer

1. ilgilinin yatırılma kararı § 63'e göre , § 66 f. 3 cümle 1'de anılan pek çok fiilden dolayı verilmişse ya da ilgili böyle bir fiili veya fiilleri § 63 'e göre yatırma kararına neden olacak fiilden önce işlemişse ve en az üç yıl hürriyeti bağlayıcı cezaya mahkum edilmişse ya da psikiyatri hastanesine zaten daha önce yatırılmışsa;

2. hükümlünün genel değerlendirilmesinde, işlediği fiillerinden ve cezanın infazı sırasındaki gelişiminden, onun mağdurun bedeni ve ruhsal sağlığına önemli bir zarar verecek ağır fiilleri işlemesi kuvvetle muhtemel olduğu sonucu çıkarılıyorsa.”

${ }^{3}$ Jescheck/Weigend, Lehrbuch des Strafrechts, Allgemeiner Teil, 5. Aufl. Berlin 1996, s. 814; BVerfG, NJW 2004, 739, 746. Bu değerlendirmeye rağmen, §§ 129 cümle 2, 134 StVollzG'e göre, emniyet tedbiri olarak müşahade altına alınan kimselerde de yeniden topluma kazandırma amacı dikkate alınmaktadır.

4 "Eğer bir kimse kasıtlı işlediği bir suçtan dolayı en az 2 yıl hürriyeti bağlayıcı cezaya çarptırılmışsa, mahkeme cezanın yanında emniyet tedbirlerine de hükmedebilir, eğer failin genel değerlendirmesi ve fiillerinin değerlendirilmesinden, onun özellikle, mağduru ruhsal ve bedensel sağlığını önemli derecede zarara uğratacak ya da ona önemli ekonomik zararlar verecek suçları işlemeye eğilimi olması nedeniyle, kamu için tehlikeli olduğu sonucu çıkıyorsa." 
ayırmak gerekir. Buna göre normal bir failden, cezasını çektikten sonra, kural olarak hukuka sadık kalacağı, hukuk kurallarına uyacağ 1 beklenilebilir. Onun kuralları ihlal etmesi, bundan sonraki yaşamında prensip olarak hukuk kurallarını hep ihlal edeceği şeklinde değerlendirilmez. Fail bir cürüm işledikten sonra da vatandaş olarak kalır. ${ }^{5}$ Ona uygulanan ceza hukuku bu yüzden vatandaş ceza hukukudur. Ancak kendisine hürriyeti sınırlandırıcı emniyet tedbiri uygulanan kişiye karşı, kelimenin tam anlamıyla tam bir tehlike kaynağı olarak mücadele edilmekte, sadece fiziksel olarak toplumdan tecrit edilmekte ${ }^{6}$ ve deyim yerinde ise gözden rak bir köşede „etkisiz hale“ 7 getirilmektedir. Jakobs hürriyeti kısıtlayıcı tedbiri açıkça, düşman ceza hukukunun ${ }^{8}$ bir örneği olarak değerlendirmekte, doktrinde bazı yazarlar ise ona analizlerinde tam olarak katılmakta ya da en azından onun fikirlerini kısmen kabul etmektedir. ${ }^{9}$

\section{Düşman Ceza Hukukunun Konsepti}

Jakobs'un en merkezi tezi Vatandaş Ceza Hukuku ve (bu hukukla karıştırılmaması ve ayrı değerlendirilmesi gereken) Düşman Ceza Hukuku ayırımıdır. $\mathrm{Bu}$ ayırımın belki de en esaslı bakış açısını, Alman ceza hukukunun belirli bir ölçüye kadar iki şeritli olması teşkil etmektedir. Bir tarafta failin kusurunun esas teşkil ettiği (Alman CK m. 46 f. 1 cümle 1 ) ${ }^{10}$ ve represif, primer açıdan geriye dönük değerlendirilmenin yapılarak, failin kural ihlaline tepki gösteren ceza hukuku bulunmakta. Diğer yanda ise Almanya'da en şiddetli devlet müdahalesi olan, hürriyeti bağlayıcı tedbiri de içine alan emniyet tedbirleri sistemi. Emniyet tedbirlerinde failin kusurunun önemi yoktur ve tedbirin alınmasının sadece ileriye dönük olarak, suçun önlenmesi bakımından gerekli olup olmadığı sorusu önem taşır. Bu tedbirin alınmasının gayesi ise, ya failin iyileştirilmesi ya da hürriyeti sınırlayıcı tedbirde olduğu gibi, toplumun failin yol açacağı tehlikelerden korunmasıdır.

Jakobs ceza hukukunu, en azından ceza hukukunun büyük bir kısmını, vatandaş ceza hukukuna dâhil etmek istemektedir. Çünkü ceza hukukunun hukuksal yürürlüğü (geçerliliği) vardır. Ona göre faile verilecek ceza, onun yaptığı işe karşı çıkma ve ona acı verme anlamına gelir. Bu acının şiddeti,

\footnotetext{
${ }^{5}$ Jakobs, ZStW 117 (2005), 839, 842.

${ }^{6}$ Jakobs, HRRS 2004, 88 vd., 90.

${ }^{7}$ Jakobs, Die deutsche Strafrechtswissenschaft vor der Jahrtausendwende, (editör: von Eser ve diğerleri), Münih 2000, s. 53.

${ }^{8}$ Jakobs, HRRS 2004, 88 vd.; ayn1 yazar, HRRS 2006, 289, 296.

${ }^{9}$ Sinn, ZIS 2006, 107, 109; Sack, http://www.cilip.de/presse/2005/sack.htm; Haffke, Sack tarafından zikredilmektedir, a.g.e.; Albrecht, ZStW 117 (2005), 852, 856; Hörnle, GA 2006, 80, 87 vd.; Arnold, HRRS 2006, 303, 304. Bu konudaki tartışmalar için bkz. Uwer (editör), "Bitte bewahren Sie Ruhe". Leben im Feindrechtsstaat, 2006.

10 "Failin kusuru cezanın miktarının tespitine esas teşkil eder."
} 
ihlal edilen normun bilişsel dayanağına zarar vermeyecek derecede olmalıdır. ${ }^{11}$

Bu da Jakobs'un Ceza teorisinden bildiğimiz şeye tekabül etmektedir. Bilindiği gibi Jakobs aynı zamanda, Positif Genel Önleme Teorisinin Almanya'daki en meşhur temsilcisidir. Jakobs ceza hukukunun amacının, insanların davranışlarında örnek olarak alacağı normun varlığını sürdürmesinde görmektedir. Toplumun beklentilerini yerine getirmeyerek, onu hayal kırıklığına uğratan kişinin, yanlış hareket ettiğini göstermek suretiyle, halkın norm beklentileri sabit hale getirilir: Yani norma olan inancın stabil hale getirilmesi, yasal geçerliliğin onaylanmasıyla sağlanmaktadır. ${ }^{12}$

Pozitif genel önleme, hukuka sadık kalanlara, yani prensip olarak hukuk düzenine sırtını çevirmemiş olan ve bu sayede de normun geçerliliği için henüz açık olan kimselere yöneliktir. Bu kimse Jakobs'un diksiyonunda vatandaştır. Bu kişi sayesinde ve cezanın da yardımıyla sembolik de olsa interaksiyon, yani karşılıklı ilişki ve diyalog (=alışveriş) gerçekleşmektedir, bu ilişkide fail şahıs olarak algılanmaktadır.

Buna karşılık düşman, örneğin terörist, pozitif genel önlemenin kapsama alanına dâhil değildir. Düşman, yani terörist prensip olarak ve aktif bir şekilde hukuk düzenine karşıdır ve düzenin rakibidir. Devletle diyaloga (iletişime) giren, devletin ceza hükmü vermesiyle karşılık verdiği, hak ve yetkilere sahip olan vatandaşın yerine tehlikeli ve tehlikeli olduğu için de kendisiyle savaşılan birey geçmektedir. Bu bireye karşı her şeyden önce çok etkili hareket edilmeli ve mümkün olduğunca çok önceden onun yolları kesilmelidir. Bunun sonucunda da iletişim yerine tehlike mücadelesi, vatandaş ceza hukuku yerine düşman ceza hukuku ortaya çıkmaktadır. ${ }^{14}$

Jakobs'un tezlerinde yeni olan, şimdiye kadar hiç duyulmamış olan nedir? Onun ceza hukukunu, ceza ve emniyet tedbirleri olarak açıklayan tezi ilk başta belli bir ölçüye kadar anlaşılabilinir, ancak bu geçtiğimiz yıllarda gerçekleşen bazı olaylarla birlikte değerlendirildiğinde patlayıcı tesiri yapabilir. Zaten Jakobs'un düşman ceza hukuku modeli hakkında yapılan şiddetli tartışmalar da bunu göstermektedir.

Jakobs konseptini bundan tam 20 y1l önce, fazla dikkat çekmeden ve zahmetsizce geliştirmişti. ${ }^{15}$ Ünlü Alman ceza hukukçusu Roxin'in 2006'da yayınlanan Ceza Hukuku Genel Hükümler kitabının 4. baskısında, düşman ceza hukukuna ayrı bir bölüm ayırması, bir tesadüf olarak kabul edilemez. ${ }^{16}$

${ }^{11}$ Jakobs, HRRS 2006, 289, 295.

12 Jakobs, Strafrecht, Allgemeiner Teil, 2. Auflage 1991, 1/Rn. 14 vd.

${ }_{13}$ Jakobs, HRRS 2004, 88.

${ }^{14}$ Jakobs, HRRS 2004, 88, 89.

${ }^{15}$ Bu konuda bkz. Greco, GA 2006, 96 vd.; Saliger, JZ 2007, 756, 757.

${ }^{16}$ Roxin, Strafrecht Allgemeinter Teil, Band I, 4. Auflage, 2006 s. 55 vd. 
Düşman ceza hukuku kavramı, 1985 yılında dikkatleri üzerine çekmeyecek bir konuda (bağlamda) oluştu. O zamanlarda Jakobs failin suçu işlemesinden önceki aşamayı, özellikle Alman Ceza Kanunu $\S 30^{\prime} \mathrm{da}^{17}$ düzenlenen teşebbüs aşamasında kalmış cürüme iştirak konusunu incelemekteydi. Jakobs burada failin devlet tarafindan vatandaş olarak değil, bilakis düşman olarak algılandığını ve muamele gördüğünü dile getirmektedir. Zira ona göre, vatandaşın serbest tasarrufuna bırakılmış içsel özel hayatına, devlet tarafindan saygı gösterilmemektedir. Çünkü devlet daha henüz dışarıya rahatsızlık olarak yansımamış ve insanın iç dünyasında oluşan düşünceye karşı tepki göstermekte ve faili bundan dolayı cezai sorumluluğa tabi tutmaktadır. Devlet, faile özel hayatına saygı duyulması gereken bir vatandaş olarak değil, tehlike kaynağı olarak karşılık vermektedir. Dolayısıyla bu hukuk, düşman ceza hukuku olarak anlaşılmalıdır. Düşman ceza hukuku, kişinin hukuk tarafından korunan yaşam, haysiyet, mal varlığ gibi değerlerinin korunmasının optimal hale getirilmesine hizmet ederken, vatandaş ceza hukuku bireyin özgürlüklerinin korunmasının optimal hale gelmesine çalışır. ${ }^{18}$

Jakobs'a göre düşman ceza hukukuna daha başka suçlardaki ön aşamalar da girmektedir. Örnek olarak da devlet aleyhine işlenen suçların yanı sıra Alman Ceza Kanunu $§ 129$ ve $\S 129 a^{\prime}$ da $^{19}$ düzenlenen ,suç işlemek ya da terör amaçlı çetelerin oluşturulması" durumlarını göstermektedir. Jakobs'a göre burada karakteristik olan, öne sürülen cezai müeyyideye rağmen, cezanın tenkisinin gerçekleşmemesidir. Terör çetelerinde, çete reisinin alacağı ceza, adam öldürmeye teşebbüs suçunun cezası kadar ağırdır. Burada çete tarafindan herhangi bir suçun teşebbüs aşamasının gerçekleşmesine gerek dahi yoktur. ${ }^{20}$ Jakobs organize suçların çeşitlerinden biri olan „ekonomik organize suçları" ve ,uyuşturucu madde ticaretine ilişskin organize suçları" da düşman ceza hukukuna dahil ederek, kapsamı genişletmektedir. Jakobs cinsel suçları da yine bu düşman ceza hukuku kategorisinde değerlendiriyor. ${ }^{21}$

Jakobs başta kendisi tarafından geliştirilen ya da kendi ifadesiyle sadece onun tarafından açığa çıkarılan düşman ceza hukukuna kritik yaklaşmaktaydı. Ona göre düşman ceza hukuku sadece istisnai olarak ve zaruret hali (olağanüstü hal) ceza hukuku olarak açıklanabilir ve kabul

17 “(1) Başkasını suç işlemeye yöneltmeye veya azmettirmeye teşebbüs eden, suça teşebbüse ilişkin hükümler gereğince cezalandırılır. Ancak ceza $\S 49$ f. 1 hükmüne göre indirilir. Aynı şekilde $\S 23 \mathrm{f} .3$ hükmü geçerlidir.

(2) Aynı şekilde, suç işlemeye veya azmettirmeye hazır olduğunu açıklayan, başkasının bu yönlü talebini kabul eden ya da başkasıyla bu konuda sözleşen kişi de cezalandırılır."

${ }^{18}$ Jakobs, ZStW 97 (1985), 751, 756.

${ }^{19}$ Jakobs, ZStW 97 (1985), 751, 756 vd.

${ }^{20}$ Jakobs, HRRS 2004, 88, 92.

${ }^{21}$ Jakobs, HRRS 2004, 88, 92. 
edilebilir. ${ }^{22}$ Düşman ceza hukukunun kapsamı mümkün olduğunca dar tutulmalıdır. Pozitif hukuk açısından, kriminalliğin ön aşamalarında daraltıcı yorum yapma imkânı bulunmaktadır. Buna karşılık Almanya'da cezaya tabi tutulan eksik teşebbüs ceza dışı kalmalıdır. ${ }^{23}$ Belirttiğimiz bu katı kritik tutum ve dikkatlerden uzak dogmatik gerekçeler nedeniyle, düssman ceza hukuku kavramı uzun yıllar gelişmedi ve dikkatlerden uzak kaldı. ${ }^{24}$

Sözünü ettiğimiz bu durum, Jakobs'un kendi cılız kalmış teorisini tekrar ele alıp, bu defa bu teoriyi açıkça destekleyen fikirlerini dile getirmesine kadar devam etti: Ona göre bugün artık düşman ceza hukukunun alternatifi yoktur. ${ }^{25}$ Eğer yok olmak istemiyorsak, teröristlere karşı yapılması gereken, soğuk savaşı bırakmaktır. ${ }^{26}$ Jabobs bu şekilde konseptini radikalleştirdi. ${ }^{27}$ Ona göre düşman ceza hukuku savaştır. Bu savaşın bütünlüğü ve etkisi, düşmandan beklenen kötülüğe bağlıdır. Jakobs bu söylediklerinin etik olmadığını ve politik açıdan doğru olmadığını itiraf etmektedir. ${ }^{28}$ Ona göre ancak geniş kapsamlı bir hukuka uygunluk olanaksızdır. ${ }^{29} \mathrm{O}$ sadece gerekli olanı tasvir etmekteymiş. ${ }^{30}$

Jakobs meslektaşlarının bu fikirleri karşısındaki kızgınlık ve şaşkınlıklarını mutlaka görmüş olmalıdır. Zira konuya ilişkin çok şiddetli ve hararetli tartışmalar yapıldı. Jakobs bu yüzden de, daha sonraki bazı açıklamalarında, baştaki radikal görüşlerini savunma gereği duydu. Son makalesinde, „düşman ceza hukukunun bu çirkin sureti ortadan kalksa, pek de memnun olurum" şeklinde bir ifade kullanıyor. ${ }^{31}$ Ancak aynı yazıda devamla bu olasılığın gerçekleşmesi için hiçbir şansın olmadığını ve düşman ceza hukukunu kastederek, bu iğrenç şeyi kabul etmek zorunda olduğumuzu belirtiyor.

Jakobs kendisine yöneltilen şiddetli eleştirileri hafifletmek için, bu defa da kendisini sadece düşman ceza hukukunun durumunu gösteren biri olarak çalışıyor. Ona gere kendisinin bulguları belirleyici değil, sadece tasvir edicidir. $O$ sadece ceza hukukundaki belirli bazı gelişmeleri analiz etmekteymiş. ${ }^{32}$ Yani şunu söylemek istiyor: Eğer bana kızıp küfrederseniz,

${ }^{22}$ Jakobs, ZStW 97 (1985), 751, 784.

${ }^{23}$ Jakobs, ZStW 97 (1985), 751, 763 vd.

${ }^{24}$ Saliger, JZ 2007, 756, 758; Greco, GA 2006, 96 vd.

25 Jakobs, Eser ve diğerleri. (editör), Die deutsche Strafrechtswissenschaft vor der Jahrtausendwende, 2000, 47, 53.

${ }^{26}$ Jakobs, HRRS 2004, 88, 92.

${ }^{27}$ Saliger, JZ 2007, 756, 758.

${ }^{28}$ Jakobs, HRRS 2006, 289.

29 Jakobs, Eser ve diğerleri (editör), Die deutsche Strafrechtswissenschaft vor der Jahrtausendwende, 2000, 47, 53.

${ }^{30}$ Jakobs, HRRS 2006, 289.

${ }^{31}$ Jakobs, HRRS 2006, 289, 290.

32 Jakobs, HRRS 2006, 289, 290. 
bununla sadece haberciye (elçiye) isabet ettirmiş olursunuz, fakat haberin kendisine değil.

Makalenin devamında artık Jakobs'la değil, düşman ceza hukuku ile uğraşmak istiyoruz. Bu yüzden onun savunma denemelerinden birine karşı kısa bir açıklama yapmak yerinde olacaktır: Jakobs, Hans-Christian Andersen'in Kralın Yeni Elbisesi masalını ima ederek "bugünkü şartlarda devlet çıplak olmalı" şeklindeki ifadesinde, kendisiyle çelişkiye düşmektedir. Burada kastedilen devletin düşman ceza hukuku ile varlığını göstermesidir. Bu ifadedeki "devlet... olmalı" ibaresi ile bile Jakobs kendi söylediğinin tersine, bir tasvir yapmamakta, bilakis bir talepte bulunmaktadır. Başka bir yerde de "asıl rakip düşmandır ve vatandaş olarak değil, düşman olarak muamele görmelidir" demektedir. ${ }^{33} \mathrm{Bu}$ sözler hiç şüphesiz hukuk politikasını ilgilendiren ve düşman ceza hukukunun propagandasını yapan mütalaalardır. ${ }^{34}$

Jakobs'un düşman ceza hukuku teorisinin en tehlikeli tarafi nedir? Bunu açıklamak için tek bir kelime yeter: „G o a n t a n a m o“. Düşman ceza hukuku Guantanamo'yu meşru hale getiriyor. Gerçi bunu Jakobs açı olarak dile getirmiyor ${ }^{35}$, fakat satır aralarında bunu görebilmek mümkün. Jakobs'un on bir eylül olaylarını işaret ederek, kendi tezi bağlamında yaptığ açıklamalarda bu daha da belli oluyor. ${ }^{36}$ Eğer devlet ilkelce ve orta çağdan kalan metotlarla gözden çıkardığı kimseleri, yakınlarına haber vermeden, avukatsız ve hiçbir hukuki koruma olmadan, tutuklayıp, gözden kaybediyorsa, bu bağımsız hukuk devletinin kendi savunmasını yapması için ona yapılan ve başına gelecekleri bildiren bir uyarı olarak algılanmalıdır. Aynı şekilde bu uygulamalarla, hukuk devleti askeri kuvvetin tamamen keyfi despotluğu şeklinde algılanır. Jakobs bunlardan başka, bir Alman İçişleri Bakanının konuya ilişkin ilginç düşüncelerine de dayanak olmuştur. Söz konusu olan bu içişleri bakanına göre, muhtemel teröristler, üçüncü şahısların hayat ve vücut bütünlüğüne yönelik herhangi bir doğrudan tehlike olmadan da tasfiye edilebilirlermiş. Zira bunlar normal vatandaş değil, düşman olduklarından, istenmeyen kişiler sıfatıyla gözden 1rak bir köşede „etkisiz hale“" getirilebilirlermiş.

Ünlü cezacı Roxin, Jakobs teorisini en can alıcı noktasından yakalıyor. Özellikle düşman ceza hukuku kavramının meşruiyetini tartışıyor ve bununla hukuka aykırı ve anti liberal cezai bir işlemin tasvip edilmiş olacağını dile getiriyor. $^{37}$

${ }^{33}$ Jakobs, HRRS 2006, 289, 294.

${ }^{34}$ Malek, HRRS 2006, 316.

${ }^{35}$ Yazar Guantanomo'yu sedece bir kez bu bağlamda zikretmiştir. Karş. Staatliche Strafe: Bedeutung und Zweck, 2004, 41 vd.

${ }^{36}$ Jakobs, HRRS 2004, 88, 92.

${ }^{37}$ Roxin, Strafrecht Allgemeinter Teil, Band I, 4. Aufl. 2006, s. 56. 
Bunun üzerine Jakobs tezini daraltıyor ve ekliyor: Düşman ve düşman ceza hukuku ile vatandaş ve vatandaş ceza hukuku kategorileri biri birinden tamamen ayrılamaz. Jakobs fiiliyatta daha ziyade karışık kişilere rastlanmakta olduğunu, bir kimsenin tamamen düşman olmasının gerekli olmadığını, kısmi düşmanlığın da söz konusu olabileceğini söylüyor. Ona göre bu iki kategori ideal örnektir ve bu yüzden gerçek hayatta rastlanılması çok mümkün olmayan, ceza hukuku dünyasının iki zıt kutbunu oluşturmaktadır. ${ }^{38}$ Acaba Jakobs tarafindan kabul edilen iki kutuplu ceza hukuku sistemi gerçekten var mıdır?

\section{Düşman Ceza Hukukunun Eleştirisi}

\section{Ampirik Açıdan Teorinin Zayıf Noktaları}

Jakobs'un söylediklerinden hareketle, onun büyük bir yanılgıda olduğu görülebilir. Onun belirttiği düşman metaforu ne Alman yasa koyucusunun görüşüne tekabül etmekte ne de yasal duruma karşl1ık gelmektedir. Jakobs'un anladığı manada suça her zaman hazır düşman kategorisi realitede mevcut değildir. Gerçek hayatta sadece ve yalnızca hukuka ve hukuk düzenine karşı olan bir insan yoktur. ${ }^{39}$ „,Bireylerin sürekli ya da en azından kararlı bir şekilde hukuka sırt çevirebilecekleri“ “ ${ }^{40}$ görüşünün anlaşılması güçtür. Sadece hukuk düzenleri değil, hukuk modelleri de konseptlerini hazırlarlarken realiteyi dikkate almak ve realiteye dayanmak zorundadırlar. ${ }^{41}$ Aksi takdirde ölçü teşkil etmezler. Tamamen hukuka sırtını dönmüş (onu inkar eden) kimselerin varlığı konusundaki şüpheler bile, düşman ceza hukukunun tüm konseptinin sağlam temeller üzerinde olmadığını göstermeye yeterlidir.

Emniyet tedbirlerinin muhatabı olan kimse, vatandaşlardan oluşan toplumun dışında değildir. Bu pek çok mahkûmiyet almış, sürücü belgesini kaybetmiş ya da genel güvenliğin korunması amacıyla hürriyeti kısıtlanarak ilgili tedavi ya da sslah evlerine kapatılanlar için de geçerlidir. Hukuka sürekli olarak sırtını dönmüş olan bu insan gruplarının varlığına ilişkin bir analiz, hayatın gerçekleriyle bağdaşmaz. ${ }^{42}$ Cinsel suçları alışkanlık haline getirmiş olan bir kimseyi toplumun bir parçası olarak görmeyerek, ona karşı savaş ilan etmek, uyuşturucu alışkanlığ 1 olan ve uyuşturucu almak için tekrar suç işleyen bir kişiye savaş açmak kadar anlaşılması ve açıklanması güç bir olaydır. Burada hukuka uygun hareket etme eğilimi, yetenek olarak eksiktir. Bunun dışında sözünü ettiğimiz bu insanlar gerçek hayatın küçük bir kesitini oluşturmaktadır. ${ }^{43}$ Kriminal bir organizasyonun üyesi olan kimse, örneğin bir

${ }^{38}$ Jakobs, HRRS 2004, 88; HRRS 2006, 289, 293.

${ }^{39}$ Schünemann, FS Nehm, 2006, 219, 225 vd.

${ }^{40}$ Jakobs, HRRS 2004, 88, 92.

${ }^{41}$ Ryffel, Grundprobleme der Rechts- und Staatsphilosophie, 1969, 352.

42 Jakobs, HRRS 2006, 289.

${ }^{43}$ Jakobs, ZStW 117 (2005), 839, 843; aynı yazar, HRRS 2006, 289, 293. 
mafya üyesi, ortalama vatandaştan potansiyel_olarak daha tehlikeli olabilir, fakat „bu kimsenin hukuk düzeninin meşruiyetini tamamen inkâr ettiği ve bu yüzden de amacının düzeni yıkmak olduğunu'“44 söylemek, dünyaya yabancı bir iddiadır. Mafya şefi (babası) de toplumun içindedir ve hukuk düzenine büyük ölçüde saygılıdır. Örneğin koca sıfatıyla aile hukuku kurallarına riayet eder. ${ }^{45}$ Mafya babası ya da terörist olmak, hukuk düzeninin kendilerini muhatap almasına engel teşkil eden bir maraz ya da eksiklik değildir. ${ }^{46}$

Esasında Jakobs'un kendisi de tezinin noksanlıklarını dile getiriyor. Özellikle tam, yüzde yüz bir düşmanın bulunmadığını, böyle bir şeyin ancak kısmen mümkün olacağını söylemek suretiyle konseptini dayandırdığg 1 temelleri kendi çökertmiştir. Zira bu söylediklerinden şu sonuç da çıkıyor: $\mathrm{Bu}$ saydığı failler aynı zamanda kısmen hukuka da uyuyorlar. Böylelikle kendi paylarına düşeni yerine getiriyorlar, topluma uyuyarak kısmen de olsa hukuka sadakati temin ediyorlar. Fakat bu defa da bunları sivil toplumdan parya gibi tamamen dişlamak mümkün olamaz. Ancak düşman ceza hukukunun konseptine göre bu kimselerin toplumdan dişlanması, tecrit edilmesi gerekir.

\section{Teorinin Semantik Zaafları}

Jakobs, cezaları ağırlaştırmak amacıyla çıkarılan bir dizi yasaya atıf yapiyor ve bu yasalarda çok açı seçik ve bariz bir düşman figürünün olduğunu iddia ediyor. Bu yasalar: „Íktisadi Suçlarla Mücadele Yasası“, „Terörle Mücadele Yasası", „Yasa Dışı Uyuşturucu Ticaretiyle Mücadele Yasası"... vs. Ona göre surf bu yasaların isimlerinde bile, bu terimlere yer verilmesi, kanun koyucunun mücadele edilmesi gereken kimseleri kişi, yani vatandaş olarak görmediğini göstermeye yeterlidir. ${ }^{47}$ Avrupa Birliği düzleminde de aynı terminoloji kullanılmaktadır. ${ }^{48}$ Ona göre bu yasalar, teknik anlamda ceza yasaları olmakla birlikte, failin cezalandırılması ikincil, tali amaçmış, bu yasalarda asıl olan teröristlere karşı mücadele imiş, tıpkı veba ve koleraya karşı mücadele gibi. ${ }^{49}$

Bir kere Jakobs yukarıda anılan mücadele yasalarında geçen „mücadele ${ }^{650}$ terimini askeri mücadele, yani savaş anlamında algılamakta. Ad1 geçen yasalar belirli suç fenomenlerine yönelik olup, belirli bir suçlu kitlesini hedef tutmamaktadır. ${ }^{51}$ Eskiden beri Almanya'da fazla ilerleme

\footnotetext{
${ }^{44}$ Jakobs, HRRS 2004, 88, 92.

${ }^{45}$ Schünemann, FS Nehm, 2006, 219, 226.

${ }^{46}$ Sinn, ZIS 2006, 107, 114.

47 Jakobs, HRRS 2004, 88, 92.

${ }^{48}$ Sinn, ZIS 2006, 107, $111 \mathrm{vd}$.

${ }^{49}$ Jakobs, ZStW 117 (2005), 839.

50 İsabetli olarak karş. Saliger, JZ 2006, 756, 760 f.; karş. Jakobs, HRRS 2004, 88, 92; aynı yazar, HRRS 2006, 289, 293.

${ }^{51}$ Kindhäuser, FS Schroeder, 2006, 81, 95.
} 
kaydedilemeyen ve genellikle de yetersiz kalan, ancak tam da başarısızlığından bahsedilemeyen ${ }^{52}$, „cinsel suçları işleyen faillerin terapisi““ hakkında Jakobs şunu söylüyor._Jakobs'un söylediklerini aktarmadan önce şu küçük hatırlatmayı yapmakta yarar var: Terapi edilecek failler, genellikle ya terapiye katılmamaktadır ya da en azından terapiye başlarda iştirak etmemektedir. $\mathrm{Bu}$ kişiler hakkında Jakobs şunları söylüyor. $\mathrm{Bu}$ kişiler kendilerine düşen görevi yerine getirmeseler de, bir düşmandan söz edilemez. Düşman konseptinin içinde sosyal terapinin yeri yoktur. O halde sonuç olarak şöyle söyleyebiliriz: Tedavi edilmek zorunda olan düşman yoktur, bilakis takip edilmek zorunda olan suçlar ve kovuşturulmak ve aynı zamanda tedavi edilmek zorunda olan failler vardır. ${ }^{53}$

\section{3) Teorinin Dogmatik Zaafları}

Jakobs'un teorisinin temelini teşkil eden düşünce şudur: Vatandaş ceza hukukunun amacını toplumsal yaşamda önem arz eden değerlerin korunması, düşman ceza hukukunun amacını ise tehlikelerle mücadele etmek oluşturmaktadır.

Jakobs, konseptinde sadece normal vatandaşlara özgülediği vatandaş ceza hukukunun da bir nebze olsun önleyici etkisinin olduğunu göz ardı etmekte. Bugün cezanın amacını açıklamak için yapılan tartışmalara bakıldığında, cezanın asıl amacının Kant'ın ileri sürdüğü gibi, failin işlediği suçun karşıllı̆ını görmesi değil, tam tersine toplumsal yaşamdaki değerlerin korunması olduğu ve bu nedenle de suçu önleyici bir fonksiyonu olduğu görüşü yaygındır. ${ }^{54}$ Punitur, sed ne peccetur, non quia peccatum est. Toplumdaki değerlerin zarar görmemesi, artık suç işlenmemesi için ceza vardır. Bu ilke sadece cezanın amacını açıklayan ve doktrinde yaygın olan karma görüş için değil ${ }^{55}$, aynı zamanda Jakobs tarafından savunulan pozitif önleme teorisi için de geçerlidir. $\mathrm{Bu}$ da kurallara riayet edilmesini sağlamakta ve gelecekte işlenmesi muhtemel suçlar karşısında koruma teşkil etmektedir. Bu yüzden de düşman ceza hukuku ve vatandaş ceza hukuku ayırımı saçmadır. Zira her ikisi de önleme amacı taşımaktadır.

İsabetli olarak işaret edildiği gibi, klasik anlamda ceza hukuku Jakobs'ca düşman olarak adlandırılan kimse karşısında da fonksiyonunu kaybetmiş değildir. Çünkü düşman, fail olarak hukukun muhatabıdır, bu muhatabın devleti kabul edip etmediği önemli değildir. ${ }^{56}$ Ceza normunun varlığı için bu soru önemli de değildir. Toplumda hukuk kuralı ihlal edilince, ceza normlarının varlığı tekrar ön plana çıkar. Genel önleme teorisinin

\footnotetext{
${ }^{52}$ Bu konuda bkz. Rosenau, StV 1999, 388, 392 vd.

${ }^{53}$ İsabetli olarak karş. Sinn, ZIS 2006, 107, 115.

${ }^{54}$ Schünemann, FS Nehm 2006, 219, 224 vd.; Kindhäuser, FS Schroeder 2006, 81, 84 vd.

${ }^{55}$ Karş. Roxin, JuS 1966, 377 vd.

${ }^{56}$ Sinn, ZIS 2006, 107, 115.
} 
konseptinde failin bireyselliğinin ve onun devleti muhatap kabul edip etmemesinin önemi yoktur. Burada hangi suçun işlendiği de önem arz etmez.

\section{Teorinin Hukuk Devleti İlkesi Açısından Zaafları}

Her şeyden önce ceza hukukunu düşman ceza hukuku ve vatandaş ceza hukuku olarak ikiye ayıran bir konseptin totaliter bir karakter taşıdığını tespit etmek gerekir. Düşman ceza hukukunun süjeye ilişkin olması, onu Kiel Ekolü'nün_savunduğu Suçlu Kategorileri Teorisi'ne yaklaştırır. ${ }^{57}$ Zira burada önemli olan failin işlediği ve hukukça korunan bir değere zarar verilmesi ya da tehlikeye sokulması sonucunu doğuran bir suç değil, bilakis failin kim olduğudur. Eğer fail vatandaşsa, ceza hukukundan yararlanır ve hukuk devleti ilkelerine göre emniyettedir. Eğer fail düşman ise, düşman ceza hukukunun araçlarıyla etkisiz hale getirilip, bir köşede tasfiye edilir. Düşman ceza hukuku konseptinin faile bu ş̧ekilde davranılmasını öngören tutumu ve devlet erkinin bu şekilde vahşileştirilmesi, faşist bir toplum düzenine neden olur. ${ }^{58}$ Hukuk devleti ilkesine göre devlet, Alman Anayasası m. 1 f. 3 'de ${ }^{59}$ yer alan vazgeçilemez ve devredilemez nitelikteki insan haklarına bağlıdır. Düşman ceza hukukunun kabul ettiği ve düşmandan bahsederken kullandığ1 „istenmeyen kişiler" ya da „vahşi hayvanlar"60 gibi metaforlar hukuk devleti ilkesiyle bağdaşmaz. Sadece belirli kişiler için özel ceza hukuku kabul edildiğinde ya da bu kişilerin statüleri inkâr edildiğinde ${ }^{61}$, anayasa hukukunun pek çok temel prensibi ihlal edilmiş olur. Özellikle de hukuk devleti ilkesi, kanun önünde herkesin eşit olduğu prensibi ve bunların da üstünde olan insan onurunun dokunulmazlığı ilkesi zedelenmiş olur. Devlet, hukuku ve hukukun geçerliliğini ceza hukukunun araçlarıyla garanti altına almak zorundadır. $\mathrm{Bu}$ da suçu suç olarak algılayıp, suçluya böyle davranmakla olur. Oysa düşman ceza hukuku anlayışı hukuku ortadan kaldırmakta ve onun yerine hukukla sonuna kadar mücadele eden bir kaba kuvveti ikame etmekte. ${ }^{62}$ Hukukun üstün tutulduğu bir devlette böyle bir konsept kesinlikle hukuken geçerli bir meşruiyete sahip değildir.

\section{Sonuç}

Makalenin girişinde hürriyeti kısıtlayıcı emniyet tedbirlerinden bahsedildi. Emniyet tedbirlerinin etrafında yapılan düşman ceza hukuku tartışmaları bir dereceye kadar anlayışla karşılanabilir. Ancak düşman ceza

57 Karş. Saliger, JZ 2006, 756, 761 ve orada anılan kaynaklar; Schönke/Schroeder/Lenckner/Eisele, Strafgesetzbuch, 27. Aufl. 2006, Vorbem. §§ 13, Rn. 5.

${ }^{58}$ Jakobs'da artık itirazları görmekte. Bkz. HRRS 2006, 289, 290.

59 "Aşağıdaki temel haklar yasama, yürütme ve yargıyı, direk geçerli hukuk kuralı sıfatıyla bağlar." hükmü Anayasa m. 1 f. 3'de yer almaktadır.

${ }^{60}$ Jakobs, Staatliche Strafe, Bedeutung und Zweck, 2004, 40 vd.

${ }^{61}$ Roxin, Strafrecht Allgemeiner Teil, 4. Aufl. 2006, 56; Kindhäuser, FS Schroeder, 2006, 81, 97 vd.; Gössel, FS Schroeder, 2006, 33, 41.

${ }^{62}$ Schünemann, FS Nehm, 2006, 219, 224. 
hukuku bilimsel açıdan, ciddi bir şekilde emniyet tedbirleri ile bağdaştırıldığında (ki gidişat bunu gösteriyor) ve tam bir model olarak alındığında hukuk devleti ilkesinin yakın zamanda erezyona uğraması kaçınılmazdır. ${ }^{63}$

Sorun emniyet tedbirleri ile ceza hukuku bağlamında yapılması gerekenler konusunda daha belirginleşmektedir. Şimdi çok sağduyulu ve hassas olmak gerekmektedir. Özellikle orant1l1lı prensibine kesinlikle riayet edilmelidir.

Alman Ceza Hukuku $\S \S 66$ vd. na ilişkin olarak ise şunlar söylenebilir: Hukuk uygulayıcısı emniyet tedbirleri için neyin kabul edildiğini hassasiyetle göz önünde tutmalıdır. Emniyet tedbirleri kriminal politikanın ${ }^{64}$ en son başvurulması gereken önlemidir. Alman Federal Mahkemesi ve Anayasa Mahkemesi ${ }^{65}$ cesaretli bir şekilde hukuk devleti erozyonuna karş1 talepte bulundular. Bu mahkemeler emniyet tedbirlerinin temel haklar ve özgürlüklere riayet edilerek yorumlanabileceğini gösterdiler. Böylelikle de düşman ceza hukukunun, emniyet tedbirlerinden doğan bir hukuk olamayacağını da ispatlamış oldular. ${ }^{66}$

\footnotetext{
${ }^{63}$ Karş. Albrecht, ZStW 117 (2005), 852, 856.

${ }^{64}$ BTDrs. V/4094, 19; BGHSt 30, 220, 222.

${ }^{65}$ Karş. 1. Kammer d. 2. Senats des BVerfG, Beschluss vom 23.8.2006 - 2 BvR 226/06; bu konuda bkz. Rosenau/Peters, JZ 2007, 584 vd.

${ }^{66}$ Rosenau, FS Venzlaff, 2006, 286 vd.
} 